\title{
Effects of Starvation on Glycogen Contents of Heart, Skeletal Muscle and Liver \\ in Several Mammals
}

\author{
Mitsuto Matsumoto and Tatsuo Hamada \\ National Institute of Animal Industry, \\ Tsukuba Norindanchi P.O. Box 5, Ibaraki-ken 305
}

(Received July 18, 1980)

\begin{abstract}
The effects of short-term starvation on cardiac, hepatic and skeletal muscle glycogen contents were observed using kids, piglets, rats, hamsters and guinea-pigs. 1) Cardiac glycogen; In the kids given a milk-replacer once daily, it was highest at $2 \mathrm{hr}$ after suckling. In the rats given a diet during the beginning of the light period, food consumption decreased it significantly $(P<0.05)$. In rats, hamsters, guinea-pigs and piglets fed ad libitum, starvation increased it. 2) Skeletal muscle glycogen; In kids and rats adapted to the restricted feeding, food consumption increased it and starvation decreased it. In the animals fed ad libitum, 33 to $59 \%$ of glycogen were lost during starvation. The piglets of 2.5 weeks old depositted $21.4 \mathrm{mg} / \mathrm{g}$ of glycogen in the feeding period. After $24 \mathrm{hr}$ starvation, $14.3 \mathrm{mg} / \mathrm{g}$ of glycogen was stored. 3) Hepatic glycogen; In the animals with ad libitum feeding, it fell by over $90 \%$ during starvation. In kids and rats with the restricted feeding, food intake increased it. 4) Plasma free fatty acids (FFA); Starvation increased it and food ingestion decreased it significantly $(P<0,05)$. A positive correlation between cardiac glycogen and plasma FFA was not found in the kics. 5) These results show that there is a cyclic change in the skeletal muscle and liver glycogen content, which is characterized as having a peak just after the meal and a nadir just before the meal, and that the cyclic change in cardiac glycogen seems to be affected by an alteration of feeding time.
\end{abstract}

Jpn. J. Zootech. Sci., 51 (12): 860-865, 1980

Glycogen contents in the liver and skeletal muscle decrease during starvation, whereas the increase in glycogen content during prolonged starvation has been observed in cardiac muscle ${ }^{1-9)}$. These changes have been discussed in connection with plasma free fatty acids (FFA) concentration ${ }^{4-7}$. It was shown in the previous paper ${ }^{3)}$ that in the rat being adapted to the restricted feeding schedule the diurnal change in cardiac glycogen content was similar to that in the serum FFA concentration.

Though it has been supposed that food intake is effective in synchronizing the diurnal change of glycogen content in the liver and skeletal muscle ${ }^{8}$, it has not been clearly shown that the change in the FFA caused by food intake regulates that of cardiac glycogen directly.

In this paper, experiments were done to confirm whether the reciprocal correlation between cardiac and hepatic or muscular glycogen during starvation and the positive correlation between cardiac glycogen and the blood FFA exist on any feeding condition or any animal species. 


\section{Materials and Methods}

\section{Animals and experimental procedures}

Kids; Nine kids were removed from their dams on the second day after birth and maintained in individual metal cages and taught to drink liquid diet from nipple bottle once daily at 0900. Daily amounts of milk-replacer solid were 60 and $82 \mathrm{~g}$ for the first 3 weeks and the following experimental period, respectively. The milk-replacer was reconstituted with warm water at a ratio of 1 to 4 . After 6 weeks of the feeding, they were divided into three groups of 3 kids of each and killed by the incision of main vessels of the neck after anesthetizing with ethyl ether at 2,24 and $48 \mathrm{hr}$ after suckling.

Rats with restricted feeding: Male rats of Wistar strain, weighing 160 to $170 \mathrm{~g}$, were caged individually in the room where temperature and humidity were controlled at $22 \pm 1^{\circ} \mathrm{C}$ and $55 \pm 5 \%$, respectively, with a light period from 0930 to 2130 . They were given a standard diet from 0930 to 1130 for 6 weeks until the day before the slaughter. On the day of the slaughter, they were divided into 2 groups of 5 rats. One group was killed just before feeding, i.e. 0930, the other group was killed at 4 hr after the start of the meal, i.e. 1330. Water was available at all times.

Piglets: Experiment was carried out from April to May. Sixteen male crossbred pigs (Landrace $\times$ Hampshire) of 2.5 weeks of age, weighing about $3 \mathrm{~kg}$, were removed from their dams. Immediately they were divided into two groups of identical body weight. Eight animals of fed group were killed by the incision of main vessels of the neck immediately after dividing, at 0900 . Remaining 8 piglets of starved group were placed in metal cage and no food or water was given. They were killed after $24 \mathrm{hr}$ starvation.

Rats, hamsters and guinea-pigs with ad libitum feeding: Eight male Wistar strain rats of 4 weeks, seven male golden hamsters of 4 weeks and six male guinea-pigs of 11 weeks of age were caged individually with exposure to natural day and night cycles during the months of May to June. The animals had free access to food and water. After 3 weeks of the feeding, they were divided into two groups of 3 to 5 animals at random at 1100. Animals of fed group were killed by decapitation immediately after dividing and the other animals were killed after $48 \mathrm{hr}$ starvation.

\section{Diets}

Rats, hamsters and guinea-pigs with ad libitum feeding were given commercial chow pellets (Oriental Yeast Co., Japan). The diet given to rats with restricted feeding was consisted of $20 \%$ casein, $5.0 \%$ soy bean oil, $70 \%$ corn starch and $5.0 \%$ other ingredients ${ }^{8}$. Preruminant kids were given milk-replacer solid consisting of $87.2 \%$ dried skimmilk, $10 \%$ lard, $2 \%$ lecithin, $0.8 \%$ other ingredients ${ }^{9}$. Piglets were given mother's milk freely until the day of experiment.

\section{Analytical methods}

In all animals used, samples of heart, liver and skeletal muscle (M. gastrocneminus) 
were removed from the carcass just after slaughter and they were placed in test tubes containing $30 \% \mathrm{KOH}$ for the subsequent glycogen analysis. Glycogen contents were determined as previously described ${ }^{3}$. At the time of slaughter, blood samples of kids, piglets and rats with restricted feeding were collected with test tube containing heparin as anticoagulant for the determination of blood plasma FFA concentrations. FFA was determined with the commercial kit (NEFA-Test Wako; Wako Pure Chemical Industries, Ltd, Osaka, Japan).

\section{Results and Discussion}

Changes in glycogen contents observed in these experiments were classified into two parts. One was the changes caused by prolonged starvation. The glycogen contents of $48 \mathrm{hr}$-starved kids, rats, hamsters and guinea-pigs, and $24 \mathrm{hr}$-starved piglets were considered. The other was $24 \mathrm{hr}$-cycle changes according to 24 -hr feeding schedule. Preruminant kids of 2 and $24 \mathrm{hr}$ starvation and rats with restricted feeding were included. Table 1 summarizes the results of experiments.

Change in glycogen contents during starvation

Aspects of fluctuation in the tissue glycogen were similar to the results shown by others ${ }^{1,2,10)}$, that is, hepatic and muscular glycogen contents decreased and cardiac

Table 1. Effects of starvation on tissue glycogen contents and plasma FFA concentration.

\begin{tabular}{|c|c|c|c|c|c|}
\hline Treatments & No. & Heart & Muscle & Liver & FFA \\
\hline Preruminant kids & & \multicolumn{3}{|c|}{ (mg/g wet weight) } & $\mathrm{mEq} / l$ \\
\hline $2 \mathrm{hr}$ after suckling & 3 & $8.72 \pm 1.0911$ & $5.25 \pm 0.71^{\mathrm{a}}$ & $30.0 \pm 2.9^{\mathrm{a}}$ & $0.298 \pm 0.064^{a}$ \\
\hline $\begin{array}{l}\text { Starved, } 24 \mathrm{hr} \\
\text { (just before feeding) }\end{array}$ & 3 & $5.68 \pm 0.72$ & $3.44=0.79^{\mathrm{a}}$ & $5.43 \pm 3.88^{\mathrm{b}}$ & $0.779 \pm 0.161^{\text {ab }}$ \\
\hline Starved, $48 \mathrm{hr}$ & 3 & $6.13 \pm 0.52$ & $1.46 \pm 0.11^{\mathrm{b}}$ & $1.54 \pm 0.15^{b}$ & $1.285 \pm 0.035^{b}$ \\
\hline \multicolumn{6}{|c|}{ Rats with restricted feeding } \\
\hline Starved, $2 \mathrm{hr}^{3)}$ & 5 & $2.84 \pm 0.25^{a}$ & $6.30 \pm 0.16^{\mathrm{a}}$ & $49.5 \pm 2.0^{\mathrm{a}}$ & $0.468 \pm 0.036^{\mathrm{a}}$ \\
\hline Starved, $22 \mathrm{hr}^{4)}$ & 5 & $3.94 \pm 0.10^{4}$ & $3.46 \pm 0.13^{b}$ & $21.5 \pm 1.8^{\mathrm{b}}$ & $1.200 \pm 0.055^{\mathrm{b}}$ \\
\hline \multicolumn{6}{|l|}{ Piglets } \\
\hline Suckling, ad libitum & 8 & $5.42 \pm 0.83$ & $21.4 \pm 2.8$ & $48.8 \pm 3.8^{\mathrm{a}}$ & $0.188 \pm 0.024^{a}$ \\
\hline Starved, $24 \mathrm{hr}$ & 8 & $6.51 \pm 0.54$ & $14.3 \pm 1.9$ & $2.60 \pm 0.56^{\mathrm{b}}$ & $0.537 \pm 0.047^{b}$ \\
\hline \multicolumn{6}{|l|}{ Rats fed ad libitum } \\
\hline Fed, ad libitum & 3 & $1.24 \pm 0.13^{a}$ & $1.79 \pm 0.61$ & $44.5 \pm 9.9^{\mathrm{a}}$ & \\
\hline Starved, $48 \mathrm{hr}$ & 5 & $4.91 \pm 0.21^{b}$ & $0.75 \pm 0.20$ & $3.33 \pm 0.53^{b}$ & \\
\hline \multicolumn{6}{|l|}{ Hamsters } \\
\hline Fed, ad libitum & 3 & $0.92 \pm 0.14^{\mathrm{a}}$ & $3.94 \pm 0.40^{\mathrm{a}}$ & $67.2 \pm 2.5^{a}$ & \\
\hline Starved, $48 \mathrm{hr}$ & 4 & $3.13 \pm 0.31^{b}$ & $1.63 \pm 0.33^{b}$ & $2.49 \pm 0.17^{b}$ & \\
\hline \multicolumn{6}{|l|}{ Guinea-pigs } \\
\hline Fed, ad libitum & 3 & $3.17 \pm 0.18$ & $4.40 \pm 0.17$ & $53.0 \pm 2.6^{2}$ & \\
\hline Starved, $48 \mathrm{hr}$ & 3 & $4.60 \pm 0.50$ & $2.90 \pm 0.56$ & $1.55 \pm 0.23^{b}$ & \\
\hline
\end{tabular}

1) Mean \pm standard error of mean. 2) Differences between figures with different superscript are significant at $5 \%$ level. 3) Corresponds to $2 \mathrm{hr}$ after the end of feeding time. 4) Corresponds to $22 \mathrm{hr}$ after the end of feeding time (just before feeding). 


\section{Changes in Glycogen Contents During Starvation}

glycogen increased during starvation. Though cardiac glycogen of the kids was the highest at $2 \mathrm{hr}$ after suckling, it was slightly higher after $48 \mathrm{hr}$ starvation than after $24 \mathrm{hr}$ starvation. It seemed to indicate that prolonged starvation increased cardiac glycogen in the kids.

The changes in glycogen contents in piglets were similar to those in rodents, but muscular glycogen content in suckling group was 4 to 10 times that was observed in other animals. In addition, $14.3 \mathrm{mg}$ of glycogen per $1 \mathrm{~g}$ tissue was stored in the skeletal muscle after $24 \mathrm{hr}$ starvation in spite of a significant decrease in hepatic glycogen. It is well known in neonatal mammals that the glycogen contents of liver, heart and skeletal muscle are very high and that immediately after birth they decrease rapidly in the liver and somewhat more slowly in skeletal muscle ${ }^{11,12}$. It had shown that newborn piglets deposit over $70 \mathrm{mg} / \mathrm{g}$ of glycogen in the skeletal muscle ${ }^{13)}$. The result obtained in this work showed that muscular glycogen content of neonatal piglets remained at a high level even after 2.5 weeks after the birth.

SUGDEN et al. ${ }^{14}$ suggested that glycogen of skeletal muscle is an important factor in carbohydrate metabolism during prolonged starvation and a potentially valuable source of blood glucose via the Cori cycle. It was shown in this experiment that hepatic glycogen of animals with ad libitum feeding fell by over $90 \%$ during starvation whereas the loss of muscular glycogen was 33 to $59 \%$. The result supports the view of Sugden et al..

\section{Cyclic change in cardiac glycogen contents}

In the experiments of $24 \mathrm{hr}$-cycle changes cardiac glycogen was the highest in the kids at $2 \mathrm{hr}$ after suckling, but ingestion of food decreased cardiac glycogen content in the rats being adapted to the restricted-feeding. The result observed in the rats was the same as those reported previously3). These results suggested that there was a cyclic change in the cardiac glycogen content and that the change in the kids was characterized as having a peak just after the meal and a nadir just before the meal and vice versa in the rats with restricted feeding.

Most experiments concerning the changes of tissue glycogen so far mainly used animals being fed ad libitum ${ }^{15-17)}$. On ad libitum feeding cardiac glycogen as well as muscular and hepatic glycogen were deposited during the time of maximal food intake ${ }^{16-18)}$. As the rat is a nocturnal animal, it consumes most of its food at night ${ }^{16,17}$. So the deposition of cardiac glycogen occurs at night. As the kid is a diurnal animal, it consumes milk from its dam during light period. In this experiment, the kid was fed in a light period, i.e., once daily at 0900 , so the increase of cardiac glycogen after suckling in the kid corresponds to the deposition of cardiac glycogen at night in the rat of ad libitum feeding. But the rat of restricted-feeding of this experiment was given the diet during the beginning of light period. This suggested that an alteration of feeding pattern could affect the cardiac glycogen metabolism.

Starvation increased the plasma FFA concentrations and food ingestion decreased them significantly $(\mathrm{P}<0.05)$. This observation was the same as those reported by 
others $^{19-21}$. In previous work, as a positive correlation between cardiac glycogen and plasma FFA was obtained in rats of restricted feeding similar to this experiment, we assumed that fluctuation in cardiac glycogen content was regulated by FFA. But a reciprocal relationship between the cardiac glycogen and FFA was reported by GARTHWAITE et al. in the rats of ad libitum feeding ${ }^{17}$. In addition, a positive correlation between cardiac glycogen and plasma FFA was not found in the preruminant kids of this experiment. Judging from these results it may be concluded that the relationship observed in the previous work ${ }^{3 \prime}$ is an apparent correlation, though the increase in cardiac glycogen content during starvation has been explained by the elevated concentration of plasma FFA ${ }^{4-7}$. Plasma FFA may play an important role in storage of cardiac glycogen during prolonged starvation but not for diurnal change.

Though glycogen content in the liver and skeletal muscle is primarily affected by feeding and affected little by lighting regimen, it is suggested that glycogen content in the heart is affected by lighting regimen. So when we discuss the mechanism by which cardiac glycogen is controlled, it is necessary to consider the difference in experimental design, especially the relationship between the lighting regimen and the feeding time.

\section{References}

1) Evans, G., J. Physiol. (London), 82: 468-480. 1934.

2) Adrouny, G. A. and J.A. Russell, Endocrinology, 59: 241-251. 1956.

3) Matsumoto, M. and R. Funabiki, J. Nutr. Sci. Vitaminol., 23: 471-474. 1977.

4) Newsholme, E. A., P. J. Randle and K. L. Manchester, Nature, 193: 270-271, 1962.

5) Garland, P. B., P. J. Randle and E. A. Newsholme, Nature, 200: 169-170. 1963.

6) Adrouny, G. A., Am. J. Physiol., 217: 686-693. 1969.

7) Neely, J. R., C.F. Whitfield and H.E. Morgan, Am. J. Physiol., 219: 1083-1088. 1970.

8) Funabiki, R., S. Ide, N. Ebe, O. Taguchi and K. Yasuda, Agric. Biol. Chem., 39: 791-793. 1975 ,

9) Matsumoto, M. and T. Hamada, Bull. Nat. Inst. Anim. Ind., 34: 29-35. 1978.

10) Ågren, G., O. Wilander, and E. Jorpes, Biochem. J., 25: 777-785. 1931.

11) Shelly, H. J., Brit. Med. Bull., 17: 137-143. 1961.

12) Sмirн, P. B., Biochim. Biophys. Acta, 628: 19-25. 1980.

13) McCance, R. A. and E. M. Widdow son, J. Physiol., 147: 124-134. 1959.

14) Sugden, M.C., S. C. Sharples and P. J. Randle, Biochem. J., 160: 817-819. 1976.

15) Segel, L. D., A. Chung, D. T. Mason and E. A. Amsterdam, Am. J. Physiol., 229: 398-401. 1975.

16) Bockman, E. L., D. K. Meyer and F. A. Purdy, Am. J. Physiol., 221: 383-387. 1971.

17) Gartuwaite, S. M., R. F. Morgan and D. K. Meyer, Proc. Soc. Exp. Biol. Med., 160: 401404. 1979.

18) Jayaram, V., D. C. S. Reddy and B.P. Naldu, Experientia, 34: 1184-1185. 1978.

19) Dore, V. P., J. Clin. Invest., 35: 150-154. 1956.

20) Fuller, R.W. and E. R. Diller, Metabolism, 19: 226-229. 1970.

21) Tanabe, S. and K. Kameoka, Br. J. Nutr., 36: 47-59. 1976. 


\title{
絶食が数種の哺乳類の心筋, 骨格筋および肝臟の グリコーゲン含量に及ぼす影響
}

\author{
松本光人・浜田龍夫 \\ 農林水産省畜産試験場, \\ 筑波農林研究団地，茨城県 305
}

心筋，骨格筋および肝蔵のグリコーダン含量に及ぼす 短期間の絶食の影響を，哺乳子山羊。哺乳子豚，ラット， メムスター，モルモットについて検討した１）心筋グ リコーゲン；1 日 1 回年前 9 時に哺乳した子山羊では， 哺乳 2 時間後に最大 $(8.72 \mathrm{mg} / \mathrm{g})$ となったが，12 時間 明暗交代下，明期の初期 2 時間の制限給慨に䵞致したラ ットでは，食䬣後有意 $(\mathrm{P}<0.05)$ 飞低下した．自由採食 させたラット，ハムスター，モルモットおよび自由哺乳 子豚では，採食あるい哺乳中に低く，絶食により增加 Lた，2）骨格筋グリコーゲン；哺乳子山羊，制限給慨 制致ラットでは，哺乳あるいは食䬲後に増加し，絶食に より減少した。自由採食させた動物でも絶食により飽食 時の 41 ない 67\%に低下した。 また，2.5 週龄の子豚 では, 哺乳中 $21.4 \mathrm{mg} / \mathrm{g}$ と他の動物の 4 ないし 10 倍量
含有されており, 絶食 24 時間後も $14.3 \mathrm{mg} / \mathrm{g}$ と高含量 であった３）肝緘グリコーゲン；自由採食させた動物で は24ないし48時間の絶食により，飽食時の10\%以下 に減少した。哺乳子山羊，制限給餉ラットです骨格筋と 同様の变化を示した，4）血槳遊離脂肪酸; 子山羊，制 限給領馿致ラット，子豚について測定したが，いずれも 哺乳あるい性食䬣直後に低下し，絶食により增加した。 心筋グリコーダンとの相関は子山羊では䜅められなか。 た．５）骨格筋と肝臟のダリコーゲンは食餌後高く，食 慨前に低い日内变動定示すことが明らかとなったが，心 筋グリコーゲンの日内变動は, 給餜時刻により変化する ことが示唆された。

日畜会報, $51(12) ： 860-865,1980$ 